\title{
The Happiest People on Earth? Scandinavian Narratives of Guilt and Discontent
}

\author{
By Elisabeth Oxfeldt, Andrew Nestingen, Peter Simonsen
}

\section{Happy Nations}

Since the first publication in 2012 of the United Nations' World Happiness Reports, the Scandinavians have repeatedly been ranked as the happiest nations in the world. ${ }^{1}$ This, as the reports argue, is not because of an intrinsic "happy" disposition among a people, but because of a welfare state that creates the conditions for high measures of happiness among its citizens. We are thus talking about evaluative happiness understood as overall contentment with life and its possibilities (provided by a social structure), as opposed to affective happiness understood as a feeling of joy at a particular moment. As revealed by the 2012 World Happiness Report, it turns out that one form of happiness does not necessarily entail the other. Denmark, for instance, ranked no. 1 on the evaluative happiness list while ranking a mere no. 100 on that of affective happiness. Whereas people in the instance of evaluative happiness, place themselves on a scale from one to ten in terms of having the worst or best possible life $^{2}$, in the case of affective happiness, they report on whether they felt happy yesterday. One can surely question the value of such rankings as Sara Ahmed for instance does in the introduction to The Promise of

\footnotetext{
${ }^{1}$ The United Nations' first World Happiness Report, published in 2012, ranked Denmark as the happiest country in the world, with Finland (2), Norway (3) and Sweden (7) following close behind. Iceland was ranked no. 20. The numbers for 2013 were: Denmark (1), Norway (2), Sweden (5), Finland (7), and Iceland (9). For 2015, the ranking had Switzerland on the top, followed by Iceland (2), Denmark (3), Norway (4), Finland (6), and Sweden (8). For 2016, the ranking was Denmark (1), Iceland (3), Norway (4), Finland (5), Sweden (10). For 2017, it was Norway (1), Denmark (2), Iceland (3), Finland (5), Sweden (10). ${ }^{2}$ Specifically, respondents are asked: "Please imagine a ladder, with steps numbered from 0 at the bottom to 10 at the top. The top of the ladder represents the best possible life for you and the bottom of the ladder represents the worst possible life for you. On which step of the ladder would you say you personally feel you stand at this time?" (Helliwell et al..2016, 9). Complicating matters, the term happy has to be translated in order to carry out international comparisons and it seems that there may be significant nuances in how this term - in translation - is understood and reported on. In the first World Happiness Report this concern is taken into consideration, and - perhaps not too surprisingly - the makers of the report maintain that the answers are correlated, reassuring "those who are concerned about interpersonal and intercultural differences in how people use words and scales when making their reports" (18). In the 2016 report, the editors once more consider the term "happy", asserting that they have evidence that asking people how "happy with life" and how "satisfied with life" they are, yields the same results: "The answers showed that income and other key variables all have the same effects on the 'happy with life' answers as on the 'satisfied with life' answers" (Helliwell et al. 2016, 12).
} 
Happiness (2010). ${ }^{3}$ Yet, from a cultural-studies perspective it would be mistaken to dismiss them on such scientific grounds considering the overall impact they have. Regardless of whether people may be self-reporting in dubious manners, whether those reporting are truly representative of the nation, and whether people are in reality replying to the same questions (to suggest but a few possible objections), the happiness reports evoke massive discursive reflection and response. In the political, social, and cultural arena, they clearly succeed in begging questions of welfare-state happiness. Whether there is a causal relationship between evaluative and affective happiness is unclear; yet what is clear is that the gap between the two types of happiness is productive, prompting a great number of (counter-)narratives about the unhappy, "happy" Scandinavian.

When it comes to evaluative happiness (i.e. general life satisfaction), the first World Happiness Report links happiness to national wealth, social equality, trust, and quality of governance - such as that of Denmark $(2012,7)$. The Nordic welfare model has indeed been based on core values of equal opportunity, social solidarity, and security for all (Esping-Andersen 1990), and at this point in time, the Scandinavian countries generally top lists measuring not only happiness, but also wealth, gender equality, class equality, social trust, and social mobility. ${ }^{4}$ This status has garnered a great deal of attention, not least in the English-speaking part of the world. After the Cold War, the Nordic welfare model has appeared to many as the only viable alternative to free-market capitalism; The Economist, for instance, published a leader in 2013 suggesting that the New Nordic Model is the Next Supermodel that others need to follow. In the U.S. 2016 presidential elections, the Scandinavian welfare-state model was once more hailed as Democratic presidential candidate Bernie Sanders regarded Nordic-style policies as exemplary of democratic socialism. ${ }^{5}$ While Sanders' visions of a more equal distribution of wealth

\footnotetext{
${ }^{3}$ Self-reporting, for one, comes across as dubious: "Happiness research is primarily based on selfreporting: studies measure how happy people say they are, presuming that if people say they are happy, they are happy. This model presumes the transparency of self-feeling (that we can say and know how we feel), as well as the unmotivated and uncomplicated nature of self-reporting [...] Measurements could be measuring the relative desire to be proximate to happiness, or even the relative desire to report on one's life well (to oneself and others), rather than simply how people feel about their life as such" (Ahmed 2010, 5).

${ }^{4}$ E.g. "Good Country Index": https://goodcountry.org/index/results

${ }^{5}$ The Nordic model is associated with a progressive middle way between socialism and capitalism, "as a kind of rational compromise between the best of two worlds" (Andersson 2009, 232).
} 
enthused many Democrats, especially among younger generations, his opponent Hillary Clinton wrote it off in a U.S. context, stating that while she liked Denmark, "We are not Denmark". ${ }^{6}$ Still, in the eyes of many people, the Scandinavians have succeeded in constructing welfare-state societies that also serve the pursuit of happiness - a salient value for so many Western nations and their citizens. ${ }^{7}$

Yet, again we ask: What does it mean to be a citizen of a "happy" country? And how does it feel? A striking number of contemporary Scandinavian narratives - written in a variety of genres and covering a wide range of media, from film and literature to educational material - indicate that being "happy" in the sense of living among the world's happiest people and being well-provided for, spurs not only a sense of pride and privilege, but also a significant amount of guilt, shame, ennui, and overall discontent. We especially find this expressed in us-them discourses, positing Scandinavians as privileged Selves vis-à-vis less-privileged Others. These presumed Others are the ones situated at the bottom of the same happiness rankings, those suffering while Scandinavians enjoy their privileges, or perhaps even those suffering so that Scandinavians may enjoy their privileges. They may be refugees hoping for a better life in the Nordic countries, immigrants picking up the jobs that established Scandinavians find undesirable, or people living in poverty in former colonies or the global South - people with whom Scandinavians become acquainted through travels abroad, through immigration, or through the daily media. These are people, whose presence stirs a wide range of emotions from strong empathy and fear, to milder forms of unease, ambivalence and what Sianne Ngai terms "ugly feelings" (Ngai 2005). They often become a source of a bad conscience. As the first World Happiness Report reminds us: "The lifestyle of the rich imperil the

\footnotetext{
${ }^{6}$ Sweden is also often referred to as the primary Nordic model. In England, the Labour party in 2006 wondered: "Can we do a Sweden?" (Andersson 2009, 237). The British Labour Party has increasingly looked to Sweden as a model and ought to keep doing so, according to Patrick Diamond, lecturer in public policy at the University of London, and former adviser to Tony Blair and Gordon Brown (Diamond 2014). Yet, as Andersson points out, other Nordic models also have high status: "In recent years there has been a remarkable comeback in the ideal of the Swedish model, if in competition with other models of Finnish schooling and Danish flexibility" (Andersson 2009, 237).

${ }^{7}$ The admirers of the Nordic model are admittedly to be found on the political Left. As Jenny Andersson puts it: "While Sweden has thus been a constant point of reference to the European and particularly AngloSaxon Left, Sweden, to a European and American liberal Right, has been a dystopian vision, a cradle-tograve society in which individual freedom was strangled" (Andersson 2009, 234).
} 
survival of the poor" $(2012,4)$. Similarly, Sara Ahmed points out: "Others suffer so that a certain 'we' can hold on to the good life" (Ahmed 2010, 195). Not surprisingly, then, being "happy" entails a fair share of guilt and discontent.

\section{An Allegorical Tale}

A good example of a contemporary us-them narrative exploring what happens when "happy" Scandinavians are confronted with the wretched Other, is Finland-Swedish author Lars Sund's En lycklig liten $\ddot{o}$ (2007; A Happy Little Island [2016]). ${ }^{8}$ The novel is written as an allegory, depicting an island community in the Finnish, Swedish-speaking archipelago. Here, people live insular, old-fashioned lives on the periphery. All know each other and have time to greet each other when they meet. Time is not strictly forward-moving, but is perceived as moving back and forth, grounding the present in the past and vice versa (101-2/84). Although they are not abundantly wealthy, they live in a democratic welfare state where all are taken care of. The general perception is that they are fortunate. As local politician K-D Mattsson puts it:

"Vår rikedom syns kanske inte i taxeringskalendern, men rika är vi - rikare än de flesta! Här har alla mat, kläder och bostad. Ingen nämnvärd arbetslöshet förekommer i Fagerö kommun och här är väl sörjt för invånarnas sociala grundtrygghet. Vi har grundskola och social trygghet. Vårt språk och vår fäderneärvda kultur binder oss samman, och vi har byggt vårt samhälle på den nordiska demokratins värdegrund." (Sund 39-40)

"Our wealth may not perhaps be visible in our tax returns, but we are rich - richer than most people! We all have food, we all have clothes, we all have shelter. There is no real unemployment in the Fagerö district and the social welfare of all our people is well taken care of. We have our school and our social security. We are bound together by our language and by the culture we have inherited from our forefathers. We have built our society on the core values of Nordic democracy." (Sund 2016, 31)

\footnotetext{
${ }^{8}$ Thank you to Philipp Wagner at Greifswald University for bringing our attention to this work.
} 
Living in such a well-functioning community is a privilege bestowed only upon a selected few in this world: "Bästa Fageröbor! Vet ni att ni har vunnit högsta vinsten på lotto? Att vara född på Fagerö - ja, det, mina vänner, är rena lottovinsten!” (40) [“dear people of Fagerö [...] Do you realize that you have won first prize in the lottery? Being born on Fagerö - that, my friends, that is the greatest prize" (31)]. Winning the global lottery is, it appears, a matter of "moral luck". Inhabitants of Fagerö (beautiful island) live longer and better lives than average people (40/31) and they deserve so on moral grounds. Evidently, they are members of a safe monocultural and monolingual community.

What prompts this speech, however, is the sudden washing ashore of about one hundred bodies of dead unidentifiable immigrants arriving from the South. First arrives a single body that all the inhabitants gather to bury - with Mattsson delivering the speech quoted above at the funeral. Then a few more bodies arrive, attracting the attention of a regional radio station whose reporter travels to the island to cover the event. Yet as the number of dead bodies increase, people's attitudes change. The radio station stops covering the arrival of bodies, and the island inhabitants are increasingly bothered by what appears as what Zygmunt Bauman (2004) would call wasted lives and Judith Butler (2009) might refer to as ungrievable lives. ${ }^{9}$ A few corpses evoke compassion and concern for origins, relatives, and sad fortunes. Many unidentified corpses, on the other hand, turn into an unwelcome burden - a logistical matter as they require autopsies, refrigerated containers, burial grounds, and may render the island less attractive as a tourist attraction. You could say that a tipping point is reached. In addition, the "happy" inhabitants of the happy island are weighed down by feelings of sorrow, guilt, and responsibility. They are marred by a combination of bad dreams and bad conscience as they wonder whether they, in some way, are to blame as accomplices, whether they should assume responsibility for

\footnotetext{
${ }^{9}$ Bauman's term is well explained on the back cover of Wasted Lives. Modernity and Its Outcasts: "The production of 'human waste' - or more precisely, wasted lives, the 'superfluous' populations of migrants, refugees and other outcasts - is an inevitable outcome of modernization. It is an unavoidable side-effect of economic progress and the quest for order which is characteristic of modernity". Bauman relates his term to similar terms used by Giorgio Agamben (homo sacer) and Stefan Czarnowski (déclassés individuals) (Bauman 2004, 32, and 40).
} 
the misery of fellow humans, and if so, what the limit of their involvement can be expected to be: “Hur mycket hjälp är det rimligt att vi ger? Var går gränsen?” (236) ["How much [can we] reasonably be expected to give. Where do we draw the line?" (196)].

In the end, the majority of the island inhabitants insist that the dead and buried bodies be removed so that things may go back to "normal" - the way things were before. Yet, we are also left with individuals who are not able to simply disregard the floating corpses arriving from the South, nor their own inclination to write these bodies off. The local minister, for instance, quits his office, condemning in a final sermon his own Othering of the dead - an Othering that many of his parishioners should be able to recognize as their own:

“Inför döden är vi människor lika, döden är vårt gemensamma öde oberoende av varifrån vi kommer, vilken hudfärg vi än har, vilket språk vi än talar. Vi har alla rätt att bli behandlade lika, oavsett om vi är döda eller levande. Men i min skräck och fasa gjorde jag dessa döda som kom hit olika oss.” (278)

"In the presence of death all humankind is equal. Death is our common fate irrespective of where we originate, of what colour we are, of which language we speak. All of us have the right to be treated as equals whether we are dead or alive. But in my fear and horror I saw the dead who came among us as different." (229)

Other inhabitants recognize their own immigrant and refugee backgrounds and maintain a sense of solidarity with the corpses, meanwhile also debunking the myth of the happy monocultural island. Finally, one of the radio reporters decides to conduct investigative journalism. She travels southward and discovers that within a global capitalist economy, so many humans are simply regarded as waste (cf. Bauman). These humans are useful as long as they can be put to work in factories, producing the Christmas decorations and electronics the privileged of the North want to buy cheaply $(243 / 201)$, but as soon as they 
cannot be exploited as labor and become homeless, unemployed, junkies, sick, parentless children (256/212), the local authorities and private businesses seek to dispose of them. The reporter ends up wondering what kind of world we are actually living in - where economics and profits are more important than human lives - yet admits that we all, of course, know this already $(243 / 202)$.

Allegorically, the happy little island may be read as representative of Nordic democratic welfare states in general - with time, perhaps, turned back a couple of decades. The dead corpses washing ashore may be read as the existence on a global level of underprivileged Others whose misery is inextricably linked to the fortunes of the lucky Scandinavians. They may be the underpaid laborers in the global South; they may be refugees trying to escape war and extreme poverty (cf. 107/89); they may be victims of human trafficking. And as suggested on the level of the fictional universe, they haunt the Northerners' dreams, while on the level of the book - i.e. as an example of a contemporary Scandinavian narrative - they haunt the Nordic imagination, contributing to - and reflective of - an understanding of the more or less guilt-ridden, not-so-happy Scandinavian. Lars Sund has written his story in the genre of an allegorical mystery novel, marked by an altmodisch narrator, quaintly addressing his reader directly, humorously commenting upon the making of his own fiction. Yet, such narratives debating the dark side of a privileged Scandinavian Self - as we shall see - exist in many other literary, educational, filmic, journalistic and informational modes and forms, comprising a general discourse that problematizes the happy Scandinavian.

\section{Questioning Happiness}

In the aftermath of the World Happiness Reports a slew of critics have raised their voices, seeking to explore a variety of apparent contradictions. Journalists have been quick to point out that Scandinavian countries also consume an inordinate amount of antidepressants and alcohol, and have high suicide rates. ${ }^{10}$ Clinical psychologist Carsten

\footnotetext{
${ }^{10}$ Hege Duckert (NRK's cultural editor), for instance, reacted against the World Happiness Reports with a comment entitled "Misfornøyd i lykkeland" (published Sept. 29, 2013). She writes that it is a paradox that the world's happiest nation, Denmark, also is among the world's greatest consumers of anti-depressants ("lykkepiller"), pointing out that the depressed become a stigmatized minority.
} 
René Jørgensen was likewise swift to respond to the happiness reports in the introduction to his book-length study on the mental health of Danes in late modernity. In Danmark på briksen [2012; Denmark on the Couch] he emphasizes the socially detrimental consequences of a Danish late modern happiness ideal that excludes a large part of the population, not least immigrants:

Er alle eller langt de fleste danskere så lykkelige, at de kan identificere sig med billedet af danskerne som verdens lykkeligste folk? Umiddelbart er der grund til at formode, at en betydelig gruppe danskere ikke helt kan genkende sig selv og deres eget liv i det glansbillede af Danmark og det ovenud lykkelige danske folk, som tegnes i disse undersøgelser. (12-3)

(Are all or most Danes so happy that they can identify with the image of Danes as the world's happiest people? Right off the bat there is reason to assume that a significant group of Danes cannot quite recognize themselves and their lives in the glossy image of Denmark and the exceptionally happy Danish people presented in these reports.)

British author Michael Booth (married to a Dane and living in Copenhagen) published his bestseller The Almost Nearly Perfect People: The Truth about the Nordic Miracle (2014), taking as his point of departure the hypothesis that Danes could not possibly be the happiest people on earth, considering how gloomy, sullen, and conformist they come across in everyday life. ${ }^{11}$ In the same book, Booth also wonders about the flag-waving Norwegians; dull, politically correct Swedes; suicidal, yet dependable, Finns; and the curiously hybrid Icelanders, questioning throughout, why these nations should be happy. Similar books written by journalists who have lived in both Scandinavian and AngloAmerican countries, are Helen Russell's The Year of Living Danishly. Uncovering the Secrets of the World's Happiest Country (2015) and Anu Partanen's The Nordic Theory of Everything. In Search of a Better Life (2016). While written from various points of view, these books share a common marveling at the apparent discrepancy between

\footnotetext{
${ }^{11}$ As Booth puts it: "Of the fifty or so nationalities that I had encountered in my travels up to that point, the Danes would probably have ranked in the bottom quarter as among the least demonstrably joyful people on earth, along with the Swedes, the Finns and the Norwegians" $(2014,2)$.
} 
evaluative and affective happiness (Scandinavians are said to be happy, but come across as gloomy), as well as a concern with outsider positions (what is it like to be unhappy in a "happy" nation? - and can a non-Scandinavian partake in the happiness?). At the same time, the works demonstrate and contribute to the cultural (performative) impact of happiness studies. Like the World Happiness Reports, these outside observations influence the Scandinavian societies as they further affect the way Scandinavians understand and negotiate their Nordic model(s) and hence also their national identities (cf. Andersson 2009, 234).

In the realm of popular culture, crime fiction and Nordic Noir narratives certainly suggest something other than "the happy Scandinavian", too, revealing a social underbelly - a dark side that clearly carries an extraordinary appeal to audiences worldwide as witnessed through the popularity of authors such as Jo Nesbø and Stieg Larsson, and TV-series including Broen (2011-2015; The Bridge) and Forbrydelsen (2007-2012; The Killing). Guilt and discomfort regarding ecology and climate changes have also come to characterize Nordic Noir, as for instance, in the TV-series Okkupert (2015; Occupied) (see Rugg's article).

Within academia, Scandinavian scholars have sought to explore and problematize the myth of the happy nation and the Nordic Model. The Gothenburg University-based project Religion, kultur och hälsa [Religion, Culture and Health], led by Yvonne Leffler, published Culture, Health, and Religion at the Millennium: Sweden Unparadised (2014) which starts out asking: "How gloomy is Sweden today?" Similarly, in connection with the research project NordWel (The Nordic Welfare State - Historical Foundations and Future Challenges), hosted by the Department of Political and Economic Studies at the University of Helsinki, Carl Marklund has edited All Well in the Welfare State? Welfare, Well-being and the Politics of Happiness (2013), in which he starts out questioning Nordic happiness:

The high score of the Nordic welfare states in the rankings of happiness could possibly indicate that the welfare state - originally concerned with the universal 
provision of basic social benefits while providing additional social support to those most in need - already makes a substantial contribution to SWB [subjective well-being - as opposed to objective well-being, EO]. Is all well in the welfare state, then? (23)

In Denmark, several academics have focused on the welfare state and its relationship to literature. Anne Marie Mai for instance has edited the anthology Kcettere, kcellinger, kontormaend og andre kunstnere (2013; Heretics, Crones, Office Workers, and Other Artists), focusing on how post-World-War-II authors engaged in the construction of the welfare state by entering into dialogue with politicians on how art and literature could contribute to ensure wellbeing in the new welfare state. In Livslange liv. Plejehjemsromaner og pensionsfortcellinger fra velfcerdsstaten (2014; Life-Long Lives. Nursinghome Novels and Retirement Stories from the Welfare State), Peter Simonsen hones in on old-age happiness in the welfare state - as it is represented in contemporary Danish novels.

In Norway, the worldwide interest in the Nordic Model has led the University of Oslo to establish "UiO: Norden" (University of Oslo: The Nordic Countries) as an interdisciplinary strategic research area, anchored at the Faculty of the Humanities (20142021). The University of Oslo also hosts the "ScanGuilt"-project, led by Elisabeth Oxfeldt, to which this set of articles is a main contribution. "ScanGuilt" is short for Post1989 Scandinavian Narratives of Guilt and Privilege. A Norwegian sister project (Scandinavian Narratives of Privilege and Guilt in an Age of Globalization) resulted in the anthology Fortellinger om skyld og privilegier i en globaliseringstid (2016; Narratives of Guilt and Privilege in an Age of Globalization) with a particular focus on Norwegian narratives of privilege and guilt. By contrast, the present collection of articles covers a broader Nordic perspective, turning its attention to Denmark, Norway, Sweden and Finland, and taking as its point of departure the idea of the "happy" nation. Overall, the project fits into the broad category of cultural studies, focusing on affect and 
emotions as they are expressed in narratives and discourses of the present, the social and political context of which is taken into consideration.

\section{Happiness Studies}

Clearly, happiness is a concept that interests people and has recently done so in new and intensifying ways. As Ahmed argues in The Promise of Happiness (2010), one may speak of a veritable "happiness turn" starting in the new millennium (3). In a 2013 anthology, the editors James O. Pawelski and D. J. Moores proclaim "the eudaimonic turn" in literary criticism using the classic Greek term eudaimonia that connotes general human flourishing and well-being (i.e. close to evaluative happiness), a turn to which Vivasian Soni's Mourning Happiness (2010) is a major contribution as it traces politically crucial redefinitions of happiness occurring in eighteenth-century novels such as Samuel Richardson's Pamela. ${ }^{12}$

The discourse of happiness is everywhere, everybody seeks happiness and they do so, in Ahmed's vocabulary, through a common, social orientation towards "happy objects" and places (21). In the allegory above, we might say that Fagerö is posited as a happy place while the immigrant corpses washing ashore are "unhappy objects" the islanders generally turn away from (Ahmed 32). Yet, as indicated above, often people do not feel happy when they expect to. This leads to a gap, evoking negative feelings such as disappointment, self-doubt or anger, and ultimately the discrepancy calls for an explanation (Ahmed 2010, 41-42). The explanation takes the form of a narrative and as the title of this anthology indicates, we are interested precisely in these stories that probe the notion and figure of the happy Scandinavian whether he or she be Danish, Norwegian, Swedish, or Finnish. What are these counter-narratives and upon which emotions other than happiness are they predicated?

\section{Happiness, Guilt, and Discontent}

\footnotetext{
12 The World Happiness Reports also take eudaimonic happiness into account, defining it as a feeling that one has a purpose or meaning in life. This is considered "an important support for subjective well-being, rather than a direct measure of it" (Helliwell et al. 2017, 10).
} 
Obviously, the term "happy" signifies various things, depending on how it is framed and understood. The term may, as previously mentioned, refer to an affective state of mind or an evaluative state of mind; cultures furthermore turn to different objects as "happy objects", with "objects" referring not only to things, but also to social institutions, such as marriage. In this vein, the Scandinavian welfare state may be regarded from the point of view of happiness and affect studies as a "happy object" - a life choice and a kind of being that leads to happiness, or rather, as Ahmed points out, that is imagined as leading to happiness (Ahmed 2010, 2). It could, as Lauren Berlant would say, be an example of "cruel optimism". In her book by that title from 2011, Berlant describes people's attachment to objects/scenarios - from food, to "a fantasy of the good life", to "a political project" - that come across as desirable, yet in fact constitute the very obstacle to that happiness and good life (Berlant 2011, 1-2). What in a Scandinavian context is referred to as "welfare nationalism" - i.e. pride in one's welfare state - may be debated as such a paradox.

A glance back at Sigmund Freud's seminal work, Civilization and Its Discontents (1961; orig. Das Unbehagen in der Kultur [1930]), illustrates that the connection between the pursuit of happiness, civilization, community building, guilt and discontent has long been explored as enigmatic and paradoxical. In fact, Freud introduces his dissertation precisely by questioning how one is to measure happiness: "It is impossible to escape the impression that people commonly use false standards of measurement - that they seek power, success and wealth for themselves and admire them in others, and that they underestimate what is of true value in life" (10). On this point, Freud's perspective agrees with that of the World Happiness Reports as they seek, precisely, to convince policy makers to consider the "happiness" of nations not in terms of GNPs, but in terms of social wellbeing based on a fair distribution of goods and of happiness (Helliwell et al. 2016, 4). Subsequently, however, the viewpoints of the World Happiness Reports and Freud diverge widely. Whereas the former follows the logic that good institutions and good governance produce happy people, Freud sees and seeks to understand the opposite. What Freud sees is that man's primary pursuit (drive) is that of happiness; which leads 
him to organize society to avoid unhappiness ${ }^{13}$; yet, in a civilized society organized to diminish unhappiness, he still ends up unhappy. This, as suggested above, could be regarded as exemplary of cruel optimism (Berlant 2011). Freud, however, explains the paradox by pointing out that "civilized man has exchanged a portion of his possibilities of happiness for a portion of security" (73). ${ }^{14}$ In other words, he has given up some of his freedom. Yet, an even greater problem is guilt -individual as well as a cultural. ${ }^{15}$ Freud's aim, in fact, is to set guilt on the social agenda: "My intention (is) to represent the sense of guilt as the most important problem in the development of civilization and to show that the price we pay for our advance in civilization is a loss of happiness through the heightening of the sense of guilt" (97). In Freud's psychological vocabulary, guilt is related to the super-ego, and there exist cultural as well as individual super-egos. The super-ego is based on, and serves to subjugate people's aggressive instincts. Yet, aggressive instincts trigger a sense of guilt, even if they are not acted upon; they need only be entertained imaginatively or subconsciously. The aggressive instinct (of destruction or death - Thanatos) is in constant conflict with man's erotic instinct (of love and human bonding - Eros). This leaves man in a bind. He may sense his ambivalence as social anxiety (85), as "a tormenting uneasiness" (99), a sort of malaise, a dissatisfaction (99), but it would be more correct to consider it, claims Freud, a sense of guilt. In this collection of articles we remain open to the question of whether all the negative emotions should be discussed as guilt. Yet, the notion of guilt does form an essential backdrop to our studies, as we also question contemporary narratives and discourses that appear to repress or deny notions of historical, postcolonial, imperial, and global guilt.

\section{Post-1989 Guilt and Discontent}

In an age of globalization being civilized Scandinavian nations entails post-Cold War global outreach. As Carl Marklund explains in a report on Nordic humanitarian action: "Since the 1990s, the Nordic states have increasingly adapted their aid and donorship

\footnotetext{
${ }^{13}$ The purpose of civilization is to limit social sources of suffering. Other sources of suffering are nature and our bodies (Freud 37).

${ }^{14}$ Freud uses the German word "Glück": "Der Kulturmensch hat für ein Stück Glücksmöglichkeit ein Stück Sicherheit eingetauscht".

${ }^{15}$ Freud writes that "it can be asserted that the community, too, evolves a super-ego under whose influence cultural development proceeds" (106).
} 
profile to international trends" (Marklund 2016,17), seeking to act as "humanitarian great powers" or "moral great powers" (Marklund 2016, 22). Yet as we saw, the citizens of Fagerö wonder when inundated by dead refugee bodies: "Hur mycket hjälp är det rimligt att vi ger? Var går gränsen?" (Sund 236) [“How much [can we] reasonably be expected to give. Where do we draw the line?" (196)]. The question of just how far the boundaries of one's community extend was a topic that Freud also touched upon as he explained that "civilization is a process [...], whose purpose is to combine single human individuals, and after that families, then races, peoples and nations, into one great unity, the unity of mankind" (81). If civilization is a process of uniting people in ever further reaching communities, then, in an age of globalization, one would expect the sense of guilt to take on a particular intensity. And as Kathleen Woodward - yet another scholar on affect in contemporary culture - concurs: "Certainly the burden of guilt many carry in the face of global conditions today is virtually intolerable" (Woodward 2009, 45).

\section{Histories of the Present}

While Freud focuses on the history of civilization and what could be considered a clash between civilization and individual happiness, Ahmed is primarily concerned with "everyday habits of happiness" (15). Situating her work within the feminist cultural studies of emotion and affect (13), she maintains a clear gendered perspective as she questions the objects to which we turn, considering, for instance, heterosexual marriage one such object. She does so, not least as a response to the discourse in which the World Happiness Reports partake as they underscore the correlation between happiness, a long life, and marriage, a correlation that may seem reassuring to a certain part of the population - those who are "happily" married, while it may be more disconcerting to those who are not, cannot, or may not have any wish to pursue their happiness through the institution of marriage. Thus, notions of happiness may be questioned from perspectives of historical guilt, moral philosophy, psychology, gender and cultural studies, to name a few.

Turning to contemporary Scandinavian texts, we find that national happiness is questioned in various ways, and that the most common expressions of discontent pertain 
to: 1) Outsiders within the nation - Ahmed's so-called "affect aliens" who do not feel happy and privileged when others evidently do (such as the refugee migrant), or who seek happiness through different "happy objects" (such as an older versus a younger generation) (see Iversen's and Nestingen's articles), 2) people who do not come across as outsiders, but suffer from ennui, ensuing from a sense of being overly well taken care of in the welfare state which in turn becomes a site of predictability and creative constraint (see Simonsen's article), 3) people experiencing a sense of historical guilt and shame related to postcolonialism and imperialism (see Körber's and Yang's articles), 4) women who indicate frustration that they never seem to master the roles of mothers, wives, career women, and global feminists all at once (see Oxfeldt's article), 5) Scandinavians experiencing a sense of guilt and bad conscience vis-à-vis a global, underprivileged Other (see Heitman's and Frøjd's articles), and 6) Scandinavians experiencing a sense of ecoguilt (see Rugg's article). As the following articles illustrate, these emotional categories do not exist in isolation, and people often feel various (combinations of) emotions in different situations.

\section{Performative Aspect of Happiness/Unhappiness Narratives}

Finally we have to ask what these narratives of guilt and discontent do. They may - given the circumstances - lead to prosocial, political behavior. Yet, there are also several ways in which they may further reify a Scandinavian position of privilege, underscoring the dichotomy of a Scandinavian We and a suffering, excluded Other. Narratives about the suffering Other may for instance evoke pity, shock and catharsis, ultimately strengthening the bonds between those who get a good cry together, a community of readers, viewers, travellers, etc. who confirm their common goodness and humanity through tears. The expression of a particular Scandinavian feeling of guilt and discontent may also strengthen an affective community. As Ahmed reminds us: "Expressing bad feeling can even become habitual in certain times and places, as a way of belonging to an affective community" (Ahmed 2010, 43). In works focusing on the suffering Scandinavian Self (as he or she confronts a suffering Other embarrassed and uncertain of what to do about it), belonging to the affective community may be less a matter of pity and catharsis and more a matter of self-irony and self-deprecating humor (cf. Ngai's 
"ugly feelings"). At the same time, affective responses do not preclude reflexive ones. One may feel pity - or experience ambivalence - express this communally, strengthening a community bond, while also reflecting further on the problem and engaging in prosocial behavior serving to break down us-them barriers and differences. ${ }^{16}$

Ultimately, hope is an important sentiment. The narratives may be read as expressions of, or calls for, hope for a happy future. As Ahmed points out, happiness is "future-oriented" and "if we hope for happiness, then we might be happy as long as we can retain this hope (a happiness that paradoxically allows us to be happy with unhappiness)" (Ahmed 2010, 181). With this paradox, we return to our initial figure of the unhappy, "happy" Scandinavian. It seems that the Scandinavian who self-reports on evaluative happiness, on thinking that he or she is part of the best possible life, may feel less than happy in the present, but still is happy in his or her belief that all circumstances are in place for him or her (and possibly his or her children) to attain happiness in the future. In terms of the social and political aspect, we are left with Scandinavians that believe in what Benedict Anderson (1998) has termed "the goodness of nations". Things may not be quite as they should right now, but one believes that one lives in a nation state that will rectify wrongs, once these wrongs are highlighted and brought to attention. At the same time, some political issues are acknowledged as transnational - or supranational - beyond the reach of the "good" nation (cf. Rugg's article).

The articles in this themed volume discuss contemporary discourses and narratives of happiness, guilt, and discontent. Our general point of departure is the notion of the Nordic model and the Scandinavian "happy" nation. Some articles focus on texts from a single nation while others are pan-Scandinavian. The order of the articles reflects an overall movement through four Nordic countries - starting with Denmark, and moving through Norway and Sweden, to end up in Finland. While the texts analyzed indicate differences between the Nordic nations, our aim has been to analyze regional Nordic

\footnotetext{
${ }^{16}$ Empirical studies carried out in a U.S. university context have for instance shown that guilt feelings are not necessarily crippling: "Although anecdotal literature often suggests that White guilt is paralyzing and debilitating among White students, empirical research suggests that White guilt is associated with positive social justice outcomes" (Spanierman et al. 2012, 182).
} 
happiness, rather than to provide a comparative study of the Nordic nations. It is our hope that our research will contribute to an increased understanding of how notions of happiness, guilt, and discontent affect people's everyday life, affect their self-image on an individual and social level, and finally affect our understanding of the emotional responses evoked by the Scandinavian welfare state and all the reports emphasizing its happiness.

We would like to thank the Norwegian Research Council for their support of this project. In addition we want to thank Fondet for Dansk-Norsk Samarbeid for granting us a stipend for a workshop at Lysebu in the fall of 2014. We also thank the Department of Scandinavian Studies at the University of Washington, Seattle, for arranging and hosting a second workshop during the fall of 2015.

\section{Bibliography}

Ahmed, Sara. 2010. The Promise of Happiness. Durham: Duke University Press.

Anderson, Benedict. 1998. The Spectre of Comparisons. Nationalism, Southeast Asia and the World. London: Verso.

Andersson, Jenny. 2009. "Nordic Nostalgia and Nordic Light. The Swedish Model as

Utopia 1930-2007”. Scandinavian Journal of History, 34:3, 229-245.

Bauman, Zygmunt. 2004. Wasted Lives. Modernity and Its Outcasts. Cambridge: Polity Press.

Berlant, Lauren. 2011. Cruel Optimism. Durham: Duke University Press.

Booth, Michael. 2014. The Almost Nearly Perfect People. The Truth about the Nordic

Miracle. London: Jonathan Cape.

Butler, Judith. 2009. Frames of War. When Is Life Grievable? London: Verso

Demker, Marie, Yvonne Leffler \& Ola Sigurdson, eds. 2014. Culture, Health, and

Religion at the Millennium. Sweden Unparadised. New York: Palgrave Macmillan.

Diamond, Patrick. 2014. "Lessons for the Labour Party from the Swedish Social Democrats' Victory". New Statesman, Sept. 17. 
http://www.newstatesman.com/politics/2014/09/lessons-labour-party-swedish-socialdemocrats-victory

Duckert, Hege. 2013. "Misfornøyd i lykkeland”. NRK Ytring, Sept. 29.

https://www.nrk.no/ytring/misfornoyd-i-lykkeland-1.11259762

Esping-Andersen, Gösta. 1990. The Three Worlds of Welfare Capitalism. Princeton:

Princeton University Press.

Freud, Sigmund. 1961 [1930]. Civilization and Its Discontents. Translated and edited by James Strachey. New York: W. W. Norton.

Helliwell, John, Richard Layard and Jeffrey Sachs, eds. 2012. World Happiness Report. New York: The Earth Institute, Columbia University.

Helliwell, John F., Richard Layard and Jeffrey Sachs, eds. 2015. World Happiness Report 2015. New York: Sustainable Development Solutions Network.

Helliwell, John, Richard Layard and Jeffrey Sachs, eds. 2016. World Happiness Report 2016, Update (Vol. I). New York: Sustainable Development Solutions Network.

Helliwell, John, Richard Layard and Jeffrey Sachs, eds. 2017. World Happiness Report 2017. New York: Sustainable Development Solutions Network.

Jørgensen, Carsten René. 2012. Danmark på briksen. Et psykologisk perspektiv på Danmark og danskerne i det senmoderne. Copenhagen: Hans Reitzels.

Mai, Anne Marie, ed. 2013. Kcettere, kcellinger, kontormcend og andre kunstnere. Forfatterroller i den danske velfcerdsstat. Odense: Syddansk universitetsforlag.

Marklund, Carl, ed. 2013. All Well in the Welfare State?: Welfare, Well-being and the Politics of Happiness. Helsinki: Nordic Centre of Excellence NordWel.

Marklund, Carl. 2013. "The Return of Happiness - the End of Utopia? Rankings of Subjective Well-Being and the Politics of Happiness". In All Well in the Welfare State?: Welfare, Well-being and the Politics of Happiness, edited by Carl Marklund, 206-32. Helsinki: Nordic Centre of Excellence NordWel. Marklund, Carl. 2016. Neutrality and solidarity in Nordic humanitarian action. London: Overseas Development Institute. (HPG Working Paper, January 2016) 
https://www.odi.org/sites/odi.org.uk/files/odi-assets/publications-opinion-files/10227.pdf

N.N. "The Next Supermodel: Politicians from both Right and Left Could Learn from the Nordic Countries". The Economist. 2 Feb. 2013. Online:

http://www.economist.com/news/leaders/21571136-politicians-both-right-and-left-couldlearn-nordic-countries-next-supermodel

Ngai, Sianne. 2005. Ugly Feelings. Cambridge: Harvard University Press.

Oxfeldt, Elisabeth, ed. 2016. Skandinaviske fortellinger om skyld og privilegier $i$ en globaliseringstid. Oslo: Universitetsforlaget.

Pawelski, James O. and D. J. Moores, eds. 2013. The Eudaimonic Turn: Well-Being in Literary Studies. Madison: Fairleigh Dickinson University Press.

Simonsen, Peter. 2014. Livslange liv. Plejehjemsromaner og pensionsfortcellinger fra velfcerdsstaten. Odense: Syddansk universitetsforlag.

Soni, Vivasian. 2010. Mourning Happiness: Narrative and the Politics of Modernity.

Ithaca: Cornell University Press.

Spanierman, Lisa B., Jacquelyn C. Beard and Nathan R. Todd. 2012. "White Men's

Fears, White Women's Tears: Examining Gender Differences in Racial Affect Types," Sex Roles 67, 174-86.

Sund, Lars. 2007. En lycklig liten ö. Helsingfors: Söderströms.

Sund, Lars. 2016. A Happy Little Island. Translated by Peter Graves. Glasgow:

Vagabond Voices.

Woodward, Kathleen. 2009. Statistical Panic. Cultural Politics and Poetics of the

Emotions. Durham: Duke University Press. 